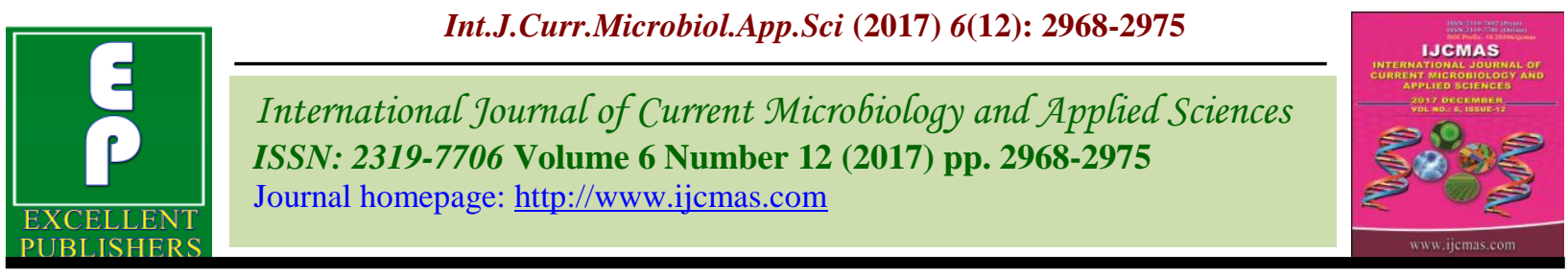

Original Research Article

https://doi.org/10.20546/ijcmas.2017.612.346

\title{
A Simple, Rapid and Effective Protocol for Extraction of Total Plant Proteins from Cotton Leaf
}

\author{
Anirudha Kumar Sahu ${ }^{1}$, I.S. Katageri1 ${ }^{1 *}$, M.P. Jadhav ${ }^{1}$ and H.M. Vamadevaiah ${ }^{2}$ \\ ${ }^{1}$ Department of Biotechnology, ${ }^{2}$ Department of Biochemistry, College of Agriculture, University \\ of Agricultural Sciences, Dharwad-580005, Karnataka, India \\ *Corresponding author
}

A B S T R A C T

\begin{tabular}{|c|c|}
\hline & \multirow{4}{*}{$\begin{array}{l}\text { An attempt was made to conceive a simple, rapid and effective method to extract total } \\
\text { plant proteins from cotton leaf samples for proteomic analysis; particularly SDS PAGE. } \\
\text { The protocol combines TCA/acetone precipitation, methanol washes and phenol extraction } \\
\text { as reported by Wang et al., (2006) with few modifications to separate the proteins from } \\
\text { several interfering compounds like lipids, polysaccharides, phenolics, terpenes, pigments, } \\
\text { organic acids, nucleic acids, free ions, proteolytic and oxidative enzymes; and precipitate } \\
\text { high-quality protein from a very low amount of starting material. The key components of } \\
\text { this protocol were water soluble PVP and DTT (those prevent oxidation of phenolic } \\
\text { compounds); and PMSF which acted as a protease inhibitor and the key step in this } \\
\text { protocol was the phenol extraction step. The overall quality of the protein was good with } \\
\text { less vertical streaking and smearing in the SDS PAGE gel and the average protein yield } \\
\text { obtained was approximately } 510 \mu \mathrm{g} / \mathrm{g} \text { fresh weight of cotton leaf. }\end{array}$} \\
\hline & \\
\hline & \\
\hline & \\
\hline
\end{tabular}

\section{Introduction}

Extraction of quality total plant protein from cotton leaf is a cumbersome process due to the presence of several interfering compounds those include lipids, polysaccharides, phenolics, terpenes, pigments, organic acids, nucleic acids, free ions, proteolytic and oxidative enzymes. Phenolics can build irreversible complexes with proteins, forming very strong hydrogen bonds with the oxygen atoms of peptide bonds or condensing with $\mathrm{SH}$ (sulfhydryl) and $-\mathrm{NH}_{2}$ (amino) groups. The oxidation of phenolics by phenoloxidases and peroxidases results in streaking in the SDS PAGE (Sodium dodecyl sulfate Polyacrylamide Gel Electrophoresis) gel. Lipids bind proteins via hydrophobic interactions, affecting their charge and relative molecular weight. In many cases the lipid-protein complex is insoluble in aqueous solution. Polysaccharides can interfere with SDS PAGE by obstructing gel pores. Nucleic acids can bind proteins through electrostatic interactions, preventing fluent gel run. Higher molecular weight nucleic acids can additionally clog the pores of the acrylamide matrix. Other substances, such as endogenous ions, nucleotide metabolites and phospholipids, which are present in the cell lysates, are often negatively charged those may interfere with the symmetrical charge distribution created by SDS (Sodium dodecyl sulfate) (Wu et al., 2014). Thus elimination of 
phenolics and other interfering compounds is a prerequisite for satisfactory protein extraction from plant tissues. In broad sense there are two different methods for total plant protein extraction; 1) Supernatant method (O'Farrell et al., 1975) and 2) precipitation method (Hurkman et al., 1986; Granier, 1988; Wang et al., 2003, 2006). In the classical supernatant method an aqueous extraction buffer is used for solublizing the total plant protein. Even though a buffer is used which solublizes all possible water soluble proteins there are heavy chances that some amount of proteins may get trapped with the debris pellet during centrifugation which reduces the yield of the proteins obtained.

The supernatant may also contain lower molecular weight interfering compounds those do not settle down by centrifugation along with trace amounts of proteolytic and oxidative compounds those may degrade the proteins. Unlike the precipitation method where the proteins are pelleted and rest other cell components are discarded with the supernatant; in the supernatant method the vice-versa is done which leads the protein to get more diluted than necessary. Thus, the precipitation method is best for extracting total plant proteins from cotton leaves. Although there are few papers published on the extraction of total proteins from plant tissues (Wu et al., 2014); no simple and exclusive protocol for the extraction of total plant proteins from cotton leaves are available. In the present study the protein extraction was done from cotton leaf using a protocol that combined TCA/Acetone precipitation, methanol washes and phenol extraction as reported by Wang et al., (2006) with few modifications introduced after referring two more papers published by Lin et al., (2014) and Du et al., (2014) independently. SDS PAGE was conducted for the analysis of the protein profile.

\section{Materials and Methods}

The present study was conducted in the Department of Biotechnology, College of Agriculture, University of Agricultural Sciences, Dharwad, Karnataka, India in the year 2017. A schematic representation of the devised protocol is given in (Figure 1). The material used in the present study to extract total plant proteins from cotton (Gossypium hirsutum var. Bikaneri Nerma) leaf and perform SDS PAGE (Sodium dodecyl sulfate Polyacrylamide Gel Electrophoresis) are $10 \%$ TCA/Acetone (Wash solution I), PVP (Polyvinyl pyrrolidone), $50 \mathrm{mM}$ PMSF (Phenyl methane sulfonyl fluoride), $40 \mathrm{mM}$ DTT (Dithiothritol), $80 \%$ Methanol plus $0.1 \mathrm{M}$ Ammonium acetate (Wash solution II), $80 \%$ Acetone (Wash solution III), 2X SDS PAGE sample buffer ( $\mathrm{pH}$ 6.8) (Table 1), $10 \%$ Water saturated phenol ( $\mathrm{pH}$ 8.0)/ SDS PAGE sample buffer (1:1), $100 \%$ Methanol (Wash solution IV), Tris-HCl (pH 6.8) (Resuspension buffer), Sample loading dye (Table 2), 1 M DTT (Dithiothritol), 30\% Acrylamide mix, 1.5 M Tris-HCl (pH 6.8, pH 8.8), 10\% SDS (Sodium dodecyl sulfate), $10 \%$ APS (Ammonium per sulfate) and TEMED (Tetra-methyl ethylenediamine).

The protein extraction was done at a low temperature of $22 \pm 3^{\circ} \mathrm{C}$ with pre-chilled mortar and pestle in an ice bath.

\section{Collection of leaf samples}

The Gossypium hirsutum var. Bikaneri Nerma plants were grown in a ventilated green house in earthen pots and the fourth and/or older leaf samples were collected from the plants at 45 days after showing for total plant protein extraction. The leaves of the plants were first sprayed with distilled water and then wiped with a kim wipe to remove dust from the surface of the leaves. Each individual sample leaf was then plucked from the plant, folded 
and wrapped in a small piece of aluminium foil and immediately dipped into liquid nitrogen for snap freezing. The protein extraction can be carried out immediately or the samples dipped in the liquid nitrogen flask can be stored at $-80^{\circ} \mathrm{C}$ for protein extraction later.

\section{Pre-chilling of reagents and crushing of samples}

The wash solutions namely $10 \%$ TCA/Acetone (Wash solution I), $80 \%$ Methanol plus $0.1 \mathrm{M}$ Ammonium acetate (Wash solution II), $80 \%$ Acetone (Wash solution III) and $100 \%$ Methanol (Wash solution IV) were pre-chilled for at least 1 hour at $-20^{\circ} \mathrm{C}$ or for at least 15 minutes at $80^{\circ} \mathrm{C}$. The other reagents were aqueous solutions and were stored at $4{ }^{\circ} \mathrm{C}$ and used directly from the refrigerator without prechilling. The $50 \mathrm{mM}$ PMSF (Phenyl methane sulfonyl fluoride) had to be prepared fresh with chilled isopropanol, ethanol or methanol for use. The mortar and pestle were also prechilled before use.

For crushing each individual leaf sample was removed from the wrapped aluminium foil in the liquid nitrogen flask and then put in the pre-chilled mortar and again crushed in liquid nitrogen for at least 10 to 15 minutes to make fine powder of the leaf sample.

\section{TCA/Acetone wash}

A very small amount i.e. 0.3 to $0.5 \mathrm{~g}$ of individual crushed leaf sample powder was weighed and $2 \mathrm{ml}$ of pre-chilled $10 \%$ TCA/Acetone (Wash solution I), $10 \mathrm{mg}$ of PVP (Poly-vinyl pyrrolidone), $8 \mu 1$ of $50 \mathrm{mM}$ PMSF (Phenyl methane sulfonyl fluoride) and $40 \mu 1$ of $40 \mathrm{mM}$ DTT (Dithiothritol) was added and crushed in a pre-chilled mortar and pestle rigorously to form a fine solution which was then transferred into a $2 \mathrm{ml}$ tube. Vortexing was done in an ice bath for not more than 2 minutes followed by centrifugation at $16000 \mathrm{xg}$ for 3 minutes at a temperature of $4^{\circ} \mathrm{C}$ in a cooling centrifuge.

\section{Methanol wash}

After removal of the supernatant in the TCA/Acetone wash a decolorized white pellet was obtained in the $2 \mathrm{ml}$ tube of each individual leaf sample. Each $2 \mathrm{ml}$ tube was then filled with pre-chilled wash solution II; namely $80 \quad \% \quad$ Methanol plus $0.1 \quad \mathrm{M}$ Ammonium acetate for further washing of the pellet. Vortexing was done in an ice bath for not more than 2 minutes followed by centrifugation at $16000 \mathrm{xg}$ for 3 minutes at a temperature of $4^{\circ} \mathrm{C}$ in a cooling centrifuge as was done in the TCA/Acetone wash step.

\section{Acetone wash and air drying}

In this step $80 \%$ Acetone (Wash solution III) was used to wash the pellet obtained after the methanol wash step. $1 \mathrm{ml}$ of $80 \%$ Acetone (Wash solution III) was added to the pellet and then it was gently dispersed in the solution by using a micro-pestle. Then $1 \mathrm{ml}$ more of $80 \%$ Acetone (Wash solution III) was added to fill the tube completely after uniformly dispersing the pellet in the wash solution. This was followed by centrifugation at $16000 \mathrm{xg}$ for 3 minutes at a temperature of $4^{\circ} \mathrm{C}$ in a cooling centrifuge.

The supernatant was discarded and the pellet was drained of the residual $80 \%$ Acetone (Wash solution III) and dried at room temperature or at $50^{\circ} \mathrm{C}$ in a thermo-mixer for at least 10 minutes. Precautions should be taken to avoid over drying of the pellet. An over-dried pellet would be difficult to resuspended in the further steps.

\section{Protein extraction and precipitation}

To the dried pellet in the previous step $1 \mathrm{ml}$ of $10 \%$ Water saturated phenol (pH 8.0)/ SDS 
PAGE sample buffer $(1: 1)$ was added and the pellet was uniformly dispersed by using a micro-pestle. Care should be taken to use the micro-pestle gently while dispersing the pellet. After uniform dispersing of the pellet in $1 \mathrm{ml}$ of $10 \%$ Water saturated phenol $(\mathrm{pH}$ 8.0)/ SDS PAGE sample buffer (1:1) mixture more $10 \%$ Water saturated phenol ( $\mathrm{pH} \mathrm{8.0)/}$ SDS PAGE sample buffer (1:1) was added to fill the tube completely.

Vortexing was done in an ice bath for not more than 2 minutes followed by centrifugation at $16000 \mathrm{xg}$ for 3 minutes at a temperature of $4^{\circ} \mathrm{C}$ in a cooling centrifuge. The tubes were removed very carefully from the cooling centrifuge so that the phenol and aqueous phase remain separated and undisturbed.

The upper phenol phase was then taken and collected in a new pre-chilled $2 \mathrm{ml}$ tube and $80 \%$ Methanol plus $0.1 \mathrm{M}$ Ammonium acetate (Wash solution II) was added to the collected phenol phase to fill the tube completely. The solution was then gently mixed by inverting in hand and then was stored in a deep freezer at $-20^{\circ} \mathrm{C}$ for 10 minutes to overnight.

\section{Final washing and air-drying the pellet}

Centrifugation of the stored sample from the previous step was done in a cooling centrifuge at $16000 \mathrm{xg}$ for 3 minutes at a temperature of $4{ }^{\circ} \mathrm{C}$ and the supernatant was discarded. The pellet was then washed once with $80 \%$ acetone (Wash solution III) and once with 100 $\%$ methanol (Wash solution IV).

During each wash step Vortexing and centrifugation was done as in the previous steps above. The pellet was then dried by inverting the tubes on a blotting paper for not more than 3 to 5 minutes. Care should be taken to avoid over-drying of the pellet.

\section{Resuspension and storage}

For resuspension; to the dried pellet in the previous step 250 to $400 \mu \mathrm{l}$ of Tris- $\mathrm{HCl}(\mathrm{pH}$ 6.8) was added and the pellet was gently dispersed by using a micro-pestle and micropipetting by intermittently keeping in ice. The pellet was tried to dissolve as far as possible as the whole pellet would not dissolve completely due to higher concentration of proteins and/or presence of insoluble proteins. The white turbid solution was then stored in a deep freezer at $-80^{\circ} \mathrm{C}$ till further use.

\section{Protein analysis by SDS PAGE}

A $12 \%$ SDS PAGE (Sodium dodecyl sulfate Polyacrylamide Gel Electrophoresis) gel was used for visualizing the proteins on the gel. A Biorad Mini-PROTEAN ${ }^{\circledR}$ Tetra Vertical Electrophoresis unit was used to set up the 12 $\%$ SDS PAGE gel electrophoresis. For casting the gel first $10 \%$ SDS (Sodium dodecyl sulfate) and $10 \%$ APS (Ammonium per Sulfate) were prepared freshly by dissolving $0.1 \mathrm{~g}$ of each of the reagent in a $1 \mathrm{ml}$ volume for each. The glass plates provided in the kit were aligned at the same level in the bottom by keeping it on a flat surface and the pair was fitted into the casting frame. The frame was then fitted to the stand and the set up was checked for gel leak. $5 \mathrm{ml}$ of resolving gel (Table 3) was prepared and introduced into the sealed space in between the two glass plates till it reached the marking of the casting frame by using a $200 \mu 1$ micropipette with an extended beaked micro-tip provided with the kit to avoid air bubble formation. The excess air bubbles were removed by adding isopropanol to the space above the resolving gel in between the glass plates which was discarded once the resolving gel was solidified. The gel was allowed to solidify for at least 45 minutes. $2.5 \mathrm{ml}$ of stacking gel (Table 4) was then prepared and poured over the solidified resolving gel. 
Fig.1 Step by step method for total plant protein extraction from cotton leaf samples

\begin{tabular}{|c|c|}
\hline Pre-chilling & $\begin{array}{l}\text { The wash solutions were pre-chilled for at least } 1 \mathrm{hr} \text { at }-20{ }^{\circ} \mathrm{C} \text { or for } 20 \text { minutes at }-80{ }^{\circ} \mathrm{C} \text {. The } \\
\text { mortar and pestle were also pre-chilled. }\end{array}$ \\
\hline Tissue powder & $\begin{array}{l}\text { The leaf sample was first sprayed with double distilled water on the plant itself and cleaned with a } \\
\text { kim wipe and then detached from the plant and placed within an aluminium foil and then was } \\
\text { dipped in liquid nitrogen immediately. } \\
\text { The isolation was done at a low room temperature }\left(22 \pm 3^{\circ} \mathrm{C}\right) \text { in a pre-chilled mortar kept on ice in } \\
\text { an ice bucket. } \\
\text { The leaf sample was removed from the liquid nitrogen and then crushed in the pre-chilled mortar } \\
\text { again by using liquid nitrogen to make fine powder. }\end{array}$ \\
\hline TCA/acetone wash & $\begin{array}{l}\text { To } 0.3 \text { to } 0.5 \mathrm{~g} \text { of leaf powder } 2 \mathrm{ml} \text { of wash solution I ( } 10 \% \mathrm{TCA} / \text { acetone }), 10 \mathrm{mg} \text { of PVP, } 8 \mu \mathrm{lof} \\
50 \mathrm{mM} \text { PMSF and } 40 \mu \mathrm{l} \text { of } 40 \mathrm{mM} \text { DTT were added. } \\
\text { The above mixture was crushed vigorously to form a uniform solution and was transferred into a } 2 \\
\text { ml tube. } \\
\text { Vortexing was done in ice for not more than } 2 \text { minutes and then centrifugation was done at } 16000 \\
\mathrm{xg} \text { for } 3 \text { minutes at } 4{ }^{\circ} \mathrm{C} \text {. }\end{array}$ \\
\hline Methanol wash & $\begin{array}{l}\text { The supernatant was then removed and the tube was filled with wash solution II ( } 80 \% \text { methanol } \\
\text { plus } 0.1 \mathrm{M} \text { ammonium acetate). } \\
\text { Vortexing was done in ice for not more than } 2 \text { minutes and then centrifugation was done at } 16000 \\
\mathrm{xg} \text { for } 3 \text { minutes at } 4{ }^{\circ} \mathrm{C} \text {. }\end{array}$ \\
\hline Acetone wash & $\begin{array}{l}\text { The supernatant was discarded and then the tube was filled with } 1 \mathrm{ml} \text { of wash solution III ( } 80 \% \\
\text { acetone) and then the pellet was gently dispersed with a micro-pestle and then } 1 \mathrm{ml} \text { more wash } \\
\text { solution III }(80 \% \text { acetone }) \text { was added. } \\
\text { The mixture was well mixed and vortexed in ice for not more than } 2 \text { minutes. The pellet had to be } \\
\text { fully dispersed. } \\
\text { Centrifugation was done at } 16000 \mathrm{xg} \text { for } 3 \text { minutes at } 4{ }^{\circ} \mathrm{C} \text { and then the supernatant was discarded. }\end{array}$ \\
\hline Drying & $\begin{array}{l}\text { Air-drying was done at room temperature or incubation was done at } 50^{\circ} \mathrm{C} \text { for at least } 10 \text { minutes } \\
\text { to remove the residual acetone. }\end{array}$ \\
\hline $\begin{array}{l}\text { Protein extraction } \\
\text { \& precipitation }\end{array}$ & $\begin{array}{l}\text { Then Saturated Phenol/SDS buffer }(1: 1) 1 \mathrm{ml} \text { was added to the tube and the pellet was gently } \\
\text { dispersed and then } 1 \mathrm{ml} \text { more of Saturated Phenol/SDS buffer }(1: 1) \text { was added to fill the tube. } \\
\text { Vortexing was done in ice for not more than } 2 \text { minutes and then centrifugation was done at } 16000 \\
\mathrm{xg} \text { for } 3 \text { minutes at } 4^{\circ} \mathrm{C} \text {. } \\
\text { Then the upper phenol phase was transferred into a new pre-chilled } 2 \mathrm{ml} \text { tube and then the tube } \\
\text { was filled with wash solution II }(80 \% \text { methanol plus } 0.1 \mathrm{M} \text { ammonium acetate }) \text { and was stored at } \\
-20^{\circ} \mathrm{C} \text { for } 10 \text { minutes to overnight. }\end{array}$ \\
\hline $\begin{array}{l}\text { Wash and air-dry } \\
\text { the pellet }\end{array}$ & $\begin{array}{l}\text { Then again centrifugation was done at } 16000 \mathrm{xg} \text { for } 3 \text { minutes at } 4{ }^{\circ} \mathrm{C} \text {. } \\
\text { The supernatant was discarded and then the pellet was washed once with wash solution III ( } 80 \% \\
\text { acetone) and once with wash solution IV }(100 \% \text { methanol). During each wash step vortexing and } \\
\text { centrifugation was done as in the previous steps above. Then the tube was inverted on a blotting } \\
\text { paper towel for } 3-5 \text { minutes for drying the pellet. }\end{array}$ \\
\hline Resuspension & $\begin{array}{l}\text { To the dried pellet then } 250 \text { to } 400 \mu \mathrm{l} \text { of Tris- } \mathrm{HCl}(\mathrm{pH} 6.8) \text { was added for resuspension and by } \\
\text { gently using a micro-pestle and pippeting the pellet was dispersed and was tried to dissolve as far } \\
\text { as possible (by intermittently keeping in ice). }\end{array}$ \\
\hline Storage & Then the sample was stored at $-80^{\circ} \mathrm{C}$ till further use. \\
\hline $\begin{array}{l}\text { Protein analysis } \\
\text { (SDS PAGE) }\end{array}$ & $\begin{array}{l}\text { For protein analysis the stored sample was then removed from }-80{ }^{\circ} \mathrm{C} \text {, thawed on ice at room } \\
\text { temperature }\left(25 \pm 3^{\circ} \mathrm{C}\right) \text { and then mixed thoroughly by inverting. The sample loading buffer }(100 \\
\mu \mathrm{l}) \text { was freshly prepared by mixing } 25 \mu \text { of DTT with } 75 \mu \mathrm{l} \text { of sample loading dye. } 8 \mu 1 \text { of the } \\
\text { freshly prepared sample loading buffer was then mixed with appropriate quantity }(15-17 \mu 1) \text { of } \\
\text { the resuspended protein sample. The mixture was then heated in a thermo-mixer or a } \\
\text { thermocycler block for } 5 \text { minutes at } 90^{\circ} \mathrm{C} \text { and then loaded into the wells of a } 12 \% \text { SDS PAGE gel. } \\
\text { The gel electrophoresis was carried out at } 80 \text { volts. }\end{array}$ \\
\hline
\end{tabular}


Fig. $212 \%$ SDS PAGE separation of cotton leaf proteins

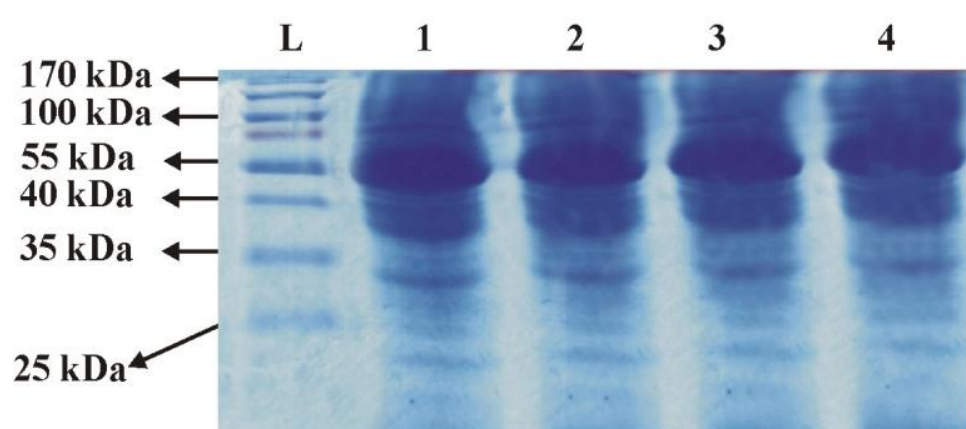

$15 \mathrm{kDa}$

$10 \mathrm{kDa}$

L: PAGE ruler $10 \mathrm{kDa}$ pre-stained protein ladder, Lane 1-4: Cotton leaf protein samples (Approximately $43-45 \mu \mathrm{g}$ of protein sample was loaded in each well)

Fig.3 Protein pellet obtained after phenol extraction and precipitation step

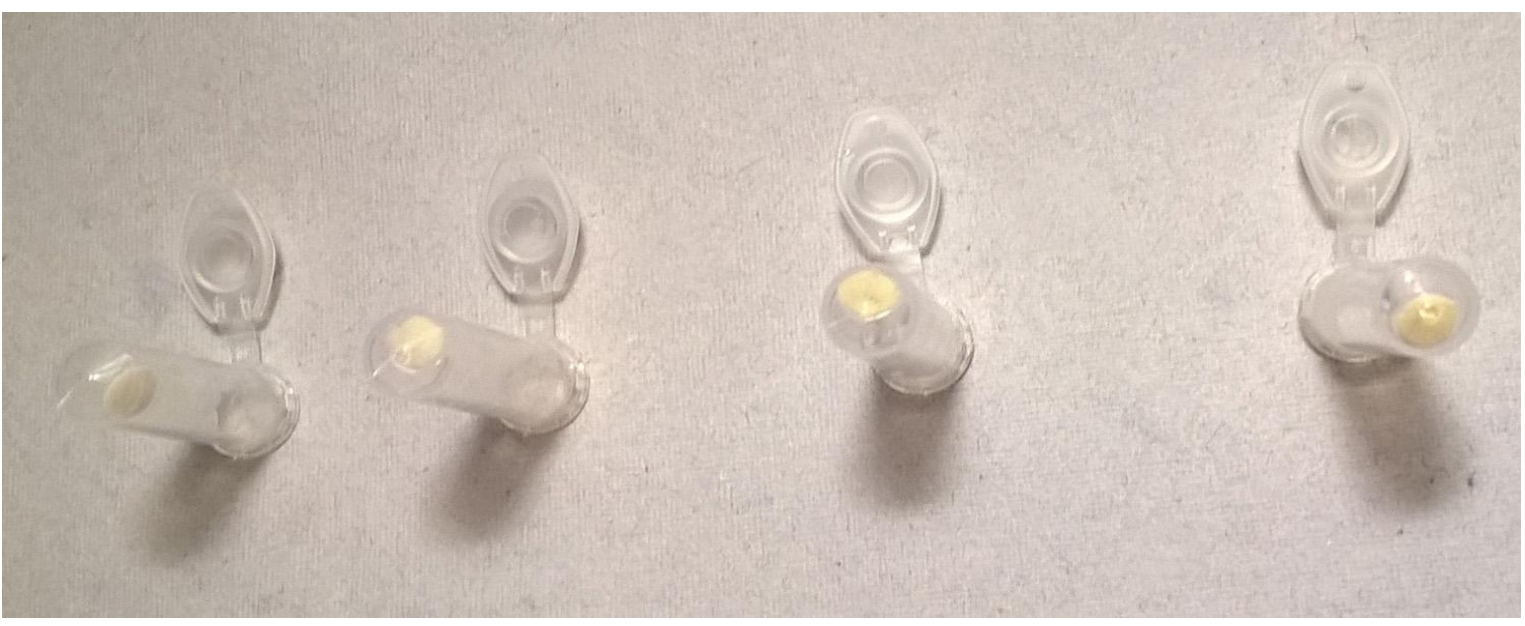

Table.1 SDS PAGE sample buffer (2X)

\begin{tabular}{|l|c|}
\hline \multicolumn{1}{|c|}{ Reagents } & Volume (ml) \\
\hline $0.5 \mathrm{M}$ Tris- $\mathrm{HCl}(\mathrm{pH} 6.8)$ & 3.75 \\
\hline $50 \%$ Glycerol & 15.0 \\
\hline $10 \% \mathrm{SDS}$ & 6.0 \\
\hline $\mathrm{ddH}_{2} \mathrm{O}$ & Volume adjusted to 30 \\
\hline
\end{tabular}


Table.2 SDS PAGE sample loading dye

\begin{tabular}{|l|c|}
\hline \multicolumn{1}{|c|}{ Reagents } & Volume \\
\hline $100 \mathrm{mM}$ Tris- $\mathrm{HCl}(\mathrm{pH} 6.8)$ & $200 \mu \mathrm{l}$ \\
\hline $200 \mathrm{mM}$ DTT & $100 \mu \mathrm{l}$ \\
\hline $20 \%$ Glycerol & $400 \mu \mathrm{l}$ \\
\hline Bromo Phenol Blue & $4 \mathrm{mg}$ \\
\hline $4 \%$ SDS & $800 \mu \mathrm{l}$ \\
\hline $\mathrm{ddH}_{2} \mathrm{O}$ & Volume adjusted to $2 \mathrm{ml}$ \\
\hline
\end{tabular}

Table.3 Composition of 12\% SDS PAGE resolving gel (5 ml)

\begin{tabular}{|l|c|}
\hline \multicolumn{1}{|c|}{ Reagents } & Volume \\
\hline $\mathrm{ddH}_{2} \mathrm{O}$ & $1.65 \mathrm{ml}$ \\
\hline $30 \%$ Acrylamide mix & $2 \mathrm{ml}$ \\
\hline $1.5 \mathrm{M}$ Tris- $\mathrm{HCl}(\mathrm{pH} 8.8)$ & $1.25 \mathrm{ml}$ \\
\hline $10 \%$ SDS & $50 \mu \mathrm{l}$ \\
\hline $10 \%$ APS & $50 \mu \mathrm{l}$ \\
\hline TEMED & $3 \mu \mathrm{l}$ \\
\hline
\end{tabular}

Table.4 Composition of 12\% SDS PAGE stacking gel (2.5 ml)

\begin{tabular}{|l|c|}
\hline \multicolumn{1}{|c|}{ Reagents } & Volume \\
\hline $\mathrm{ddH}_{2} \mathrm{O}$ & $1.7 \mathrm{ml}$ \\
\hline $30 \%$ Acrylamide mix & $425 \mu \mathrm{l}$ \\
\hline $1.5 \mathrm{M}$ Tris- $\mathrm{HCl}(\mathrm{pH} 8.8)$ & $312.50 \mu \mathrm{l}$ \\
\hline $10 \%$ SDS & $25 \mu \mathrm{l}$ \\
\hline $10 \%$ APS & $25 \mu \mathrm{l}$ \\
\hline TEMED & $2.5 \mu \mathrm{l}$ \\
\hline
\end{tabular}

The comb was inserted carefully to avoid introduction of air bubbles just after the stacking gel was poured and the gel was allowed to solidify for at least 30 minutes.

The set up was then removed from the stand and attached with the electrode unit and then immersed into the tank buffer for electrophoresis.

The concentration of the protein samples before loading was checked by Lowry method (methodology not mentioned). For analysis each individual protein sample was removed from $80^{\circ} \mathrm{C}$ and thawed on ice at room temperature followed by mixing thoroughly by inverting and micro-pipetting. $100 \mu \mathrm{l}$ of fresh sample loading buffer (Table 1) was then prepared by mixing $25 \mu \mathrm{l}$ of DTT (Dithiothritol) with $75 \mu \mathrm{l}$ of sample loading dye (Table 2). $8 \mu$ l of sample loading buffer was then mixed with 15 to $17 \mu \mathrm{l}$ of individual resuspended protein sample and the mixture was heated for denaturation to monomers on a thermomixer or a thermocycler block for 5 minutes at $90^{\circ} \mathrm{C}$ and then each of them was loaded into the wells of a $12 \%$ SDS PAGE gel alongside a PAGE RULER $10 \mathrm{kDa}$ prestained ladder and electrophoresis was done at 80 volts.

\section{Results and Discussion}

This protocol facilitated the extraction of highquality protein samples from cotton leaf suitable 
for SDS PAGE electrophoretic analysis. The overall quality of the protein was good with less vertical streaking and smearing in the SDS PAGE gel (Figure 2). The protein estimation was done by Lowry method. The average protein yield obtained was approximately 510 $\mu \mathrm{g} / \mathrm{g}$ fresh weight of cotton leaf.

The efficient extraction of proteins from the cotton leaf tissue depends on the time interval in between plucking the leaf and snap freezing (i.e. dipping in liquid nitrogen), the quality of sample disruption, the room temperature at which the extraction is carried out and the time gap in between two consecutive steps. The key components of this protocol were water soluble PVP and DTT (those prevent oxidation of phenolic compounds); and PMSF which acted as a protease inhibitor.

The $10 \%$ TCA/Acetone wash turned the tissue pellet white or light colour indicating the removal of majority of the secondary metabolites such as pigments and phenolics (Wu et al., 2014). The key step in this protocol was the phenol extraction step in which the proteins were first extracted as a pellet after washing and then dispersed in the $10 \%$ water saturated phenol ( $\mathrm{pH}$ 8.0)/ SDS PAGE sample buffer (Wang et al., 2006) causing proteins to denature and dissolve in the phenol phase, whereas other water-soluble substances (e.g., salts, nucleic acids, and carbohydrates) remained in the aqueous phase ( $\mathrm{Wu}$ et al., 2014).

Proteins in the phenol phase were then purified and concentrated simultaneously by subsequent methanol precipitation (Figure 3). The protocol required very low starting material i.e. maximum $1 \mathrm{~g}$ of leaf powder for extracting proteins enough to conduct SDS PAGE for at least four times and was found to be very simple and effective for extracting high-quality total plant proteins from cotton leaf.

\section{References}

Du, M., Li, Y., Tian, X., Duan, L., Zhang, M., Tan, W., Xu, D. and Li, Z., 2014. The phytotoxin coronatine induces abscissionrelated gene expression and boll ripening during defoliation of cotton. PLOS ONE 9(5): e97652.

Granier, F., 1988, Extraction of plant proteins for two-dimensional electrophoresis. Electrophoresis, 9: 712-718.

Hurkman, W. J., Tanaka, C. K., 1986, Solubilization of plant membrane proteins for analysis by two-dimensional electrophoresis. Plant Physiol. 81: 802806.

Lin, D. G. and Wang, C. S., 2014, Extraction of total proteins from rice plant. Bioprotocol, 4 (21): 1-8.

O'Farrell, P. H., 1975, High resolution twodimensional electrophoresis of proteins. $J$. Biol. Chem. 250: 4007-4021.

Wang, W., Scali, M., Vignani, R., Spadafora, A., 2003, Protein extraction for twodimensional electrophoresis from olive leaf, a plant tissue containing high levels of interfering compounds Electrophoresis 24: 2369-2375.

Wang, W., Vignani, R, Scali, M. and Cresti, M, 2006, A universal and rapid protocol for protein extraction from recalcitrant plant tissues for proteomic analysis. Electrophoresis, 27: 2782-2786.

Wu, X., Gong, F. and Wang, W., 2014, Protein extraction from plant tissues for $2 \mathrm{DE}$ and its application in proteomic analysis. Proteomics, 14: 645-658.

\section{How to cite this article:}

Anirudha Kumar Sahu, I.S. Katageri, M.P. Jadhav and Vamadevaiah, H.M. 2017. A Simple, Rapid and Effective Protocol for Extraction of Total Plant Proteins from Cotton Leaf. Int.J.Curr.Microbiol.App.Sci. 6(12): 2968-2975. doi: https://doi.org/10.20546/ijcmas.2017.612.346 